\title{
EL IMAGINARIO DEL VINO EN LA LITERATURA MEDIEVAL: LA DUALIDAD VIDA-MUERTE
}

\author{
María Jesús Salinero Cascante* \\ Universidad de La Rioja
}

\author{
A Carmelo, un buen compañero y una buena persona
}

\begin{abstract}
RESUMEN: El vino en el imaginario de la cultura medieval se asocia con las dos caras de la existencia humana: la vida y la muerte, siendo por ello objeto de una doble valoración. Dentro de esta dialéctica hay una visión positiva del vino y del beber por su asociación real y metafórica con la vida y el buen vivir, generando imágenes reconfortantes de alegría y exaltación. La visión negativa asocia el vino con la embriaguez, la enfermedad y la muerte dejando imágenes de decadencia física, económica y espiritual porque, como claman las voces de clérigos y moralistas, la embriaguez es un pecado (muerte del alma) ligado a la gula, y fuente de otros como la lujuria, la infidelidad, la ira. Así pues, la ambivalencia y la ambigüedad rigen el imaginario del vino medieval, aunque en ocasiones la antífrasis opera el cambio (el mundo al revés) y la vida se cuela por las rendijas de la muerte instaurando otra forma de existencia dichosa: la inmortalidad.
\end{abstract}

ABSTRACT: Wine in Medieval Culture imagery is associated with the two sides of human existence: life and death. It is thus the object of two analytical perspectives. In the tension between these two perspectives we find a positive vision of wine drinking in terms of both its real and metaphorical relation to the joys of good living, thus leaving us with comforting images of grandeur and bliss. The negative vision, in its turn, links wine with drunkenness, disease and death, constructing images of physical, economical and spiritual decadence. This is so because, as the clergy and other moralists proclaim, drunkenness is sin (the death of the soul), it is closely linked to gluttony and it lies at the origin of other forms of sinful behavior such as lust, infidelity, and anger. We conclude that ambivalence and ambiguity govern the imagistic expression of wine in the Middle Ages, although at some point antiphrasis will bring about the change -the world upside down-and life will pour in through the cracks of death thereby giving rise to another form of blissful existence: immortality.

PALABRAS CLAVE: Vino, vida, muerte, gloria, miseria, Literatura Medieval Francesa e Ibérica.

KEYWORDS: Wine, life, death, joy, misery, French and Iberian Medieval Literature.

\footnotetext{
* La autora pertenece al Centro de Investigación Aplicada y Multidisciplinar del Vino y de la Agroalimentación en la Universidad de La Rioja (CIVA) y es responsable del Grupo de Investigación Cultura y Vino de la Universidad de La Rioja. Este artículo entronca con la línea de investigación "El vino en la Literatura y la Cultura ibérica y francesa" y está vinculado al proyecto API-07/A15 de la Universidad de La Rioja-Banco Santander.
} 


\section{Introducción}

El vino es hoy día un valor económico en alza por su cuidada producción y comercialización. Este primer valor se enriquece con la marcada apreciación que nuestra sociedad concede al vino como valor social y cultural porque el vino forma parte de la cultura (incluso se habla de "la cultura del vino), se plasma en el arte, y se identifica con ese "saber vivir" o "buen vivir", meta perseguida por muchos como modelo de vida.

El vino es considerado en nuestros días como el producto final de un conjunto de factores naturales, de labores agrícolas y tecnológicas: una buena cepa, un buen terreno ("le terroir") del que toma la vid su savia, un clima y altitud adecuados, un regadío acertado y un viticultor diestro conocedor de su crianza y elaboración. El resultado de todo este complejo universo es un líquido precioso y apreciado desde la Antigüedad, quinta esencia destilada de la cepa, un misterio en sí mismo que ha sido objeto de creencias, ritos y tradiciones, algunos marcadamente esotéricos (como los cultos a Dioniso o las Bacanales romanas) en los que el vino exaltaba los sentidos como medio de alcanzar la clarividencia, o de participar en lo sagrado (de su esencia e inmortalidad) al transcender el plano terrenal.

Pero sobre todo, el vino es considerado desde su origen fuente de vida. La viña en latín es vitis, siendo evidente su proximidad con otro término latino: vita (vida). Ahora bien, la vida no se entiende sin su contrario la muerte. Ambas marcan la existencia y ambas configurarán el imaginario simbólico del vino porque la cepa y el vino forman parte de la naturaleza y de sus ciclos. Rabelais, el autor del Renacimiento que más ha exaltado el vino, lo sabe muy bien y él mismo ejemplifica esta dualidad vida vs muerte: "Je mouille, je humecte, je boy, et tout de peur de mourir" (dice uno de los bebedores de Gargantúa, al que se le responde:) "Buvez toujours, vous ne mourrez jamais" .

Por otra parte, este ritmo cíclico de la vid y del vino nos permite asociarlo con los mitos y ritos de vegetación y fertilidad que según los antropólogos tienen su origen en los periodos más remotos de la Humanidad. Nos referimos fundamentalmente al trayecto:

$$
\text { vida } \rightarrow \text { muerte } \rightarrow \text { renacimiento }
$$

1. Para una visión de conjunto del tema del vino y de la embriaguez en Rabelais remitimos a M. Bideaux, R. O’Hanion et J.-M. Picard (eds.). Rabelais-Dionysos, vin, carnaval, ivresse. Montpellier: Jeanne Laffitte, 1997. 
Apliquemos este recorrido, grosso modo, al vino. La vida está representada por la Madre Tierra donde todo se inicia, por la cepa y la vid, su fruto. La muerte por la vendimia y por la manipulación en la bodega. Estas dos fases se asimilan con el sacrificio ritual de muchas culturas y con el sacrificio mitológico de dioses como los egipcios Attis y Osiris, el griego Dioniso, o la diosa celta Epona y, desde luego, en la religión cristiana con Jesucristo ${ }^{2}$. Todos ellos mueren y son enterrados. Esta fase oscura la identificamos con el tiempo que el vino duerme en barrica en lo profundo de la tierra junto a otras barricas en naves subterráneas, auténticas necrópolis o cementerios enológicos. Ahora bien, no nos equivoquemos, la muerte metafórica es siempre, y así se expresa en los ritos y mitos, una fase positiva y regeneradora para devenir otro más completo ${ }^{3}$. El renacimiento sobreviene cuando se completa el ciclo y se ha alcanzado la perfección corporal (los dioses vuelven a la vida en todo su esplendor y magnificencia), es decir, cuando ha adquirido todas sus virtudes y una identidad propia. Es el elixir de los alquímicos que se deposita, como el valioso oro, en el fondo de la copela.

Como hemos dicho, el vino es en nuestros días una bebida muy apreciada que forma parte de la vida cotidiana y de los grandes festejos. También hemos mostrado, al hilo de un pasaje de Rabelais, que el vino simboliza o se asocia con las dos caras de la existencia, lo que según los parámetros de una época se puede convertir en objeto de una doble valoración: positiva por su relación con la vida y negativa por su relación con la muerte. ¿Es esta doble valoración la que impera en la Edad Media? Para responder a esta pregunta nos parece fundamental establecer, en primer lugar, los mecanismos rectores de la mentalidad medieval que evitarán que erremos en nuestras valoraciones. En segundo lugar, analizaremos el vino y su simbolismo sirviéndonos de los textos medievales y aplicando los dos valores vida-muerte que nos permiten centrar el tema, aunque dada su amplitud, nos limitaremos en esta ocasión a establecer consideraciones generales esperando volver posteriormente con estudios más parcelados y específicos.

\section{La Edad Media y la antítesis}

La pareja de contrarios vida vs muerte encaja a la perfección en un sistema como el medieval con su visión dualista del universo: "La culture médiévale nous

2. De estos ejemplos el más cercano y evidente es el de Jesucristo cuyo cuerpo y sangre se convierten simbólicamente en alimento espiritual y de vida, ambos representados por la hostia y el vino consagrados.

3. Estamos hablando de una regeneración corporal total, lo que se llama "la fase de crisálida". Ver G. Bachelard. La Terre et les rêveries du repos. París: José Corti, 1948. 
apparaît perpétuellement comme une impossible combinaison d'oppositions"4. Un dualismo, herencia de antiguas culturas como la griega y la judia, que se enraíza en la civilización cristiana y prende con fuerza en la corriente cátara ${ }^{5}$. Sea como fuere, lo cierto es que la literatura medieval es tributaria de este maniqueísmo que instaura, como dirá Gilbert Durand ${ }^{6}$, todo un Régimen de la antítesis que estructura las imágenes y los símbolos en torno a dos polos: uno positivo y otro negativo. El Bien (Dios) oponiéndose al Mal (el demonio) es el origen de toda una serie de valores espirituales ${ }^{7}$ o sociales ${ }^{8}$ que se contraponen como virtud vs pecado y orden vs desorden. Esta visión dicotómica y fuertemente moralista influirá en el tema que hemos elegido de manera que el vino será enfocado positiva o negativamente, tanto en el plano real como en el metafórico, según se relacione con la vida o con la muerte, los dos extremos de una misma realidad (la existencia de todo ser vivo), aunque no siempre será así porque "la mort et la vie qui dans toutes les conceptions du monde sont des contraires radicalement opposés, sont parfois réversibles et la frontière qui les sépare n'est pas étanche"'.

El Occidente medieval, y fundamentalmente el Mediterráneo, vive de la agricultura siendo el viñedo uno de los cultivos más expandidos. Esta civilización aprecia el vino como antes lo apreciaron griegos y romanos, y como también lo aprecian otras culturas: los musulmanes instalados en el al-Andalus y en países más alejados como Irán en los que se tolera el consumo de vino a pesar de la prohibición coránica ${ }^{10}$. En definitiva, en el Occidente medieval se cultiva el viñedo, se hace vino y se bebe vino.

El vino se adhiere a la vida porque proviene de la vida y participa en la vida del hombre medieval, tanto en la vida cotidiana (en la mesa) como en momentos especiales -festines, convites y festejos- generando imágenes sonrientes de fiesta y regocijo. Además, se considera al vino una bebida reconstituyente y hasta curativa. En fin, el vino es vida o retomando las palabras de Rabelais, una pro-

4. A. Gourevitch. Les catégories de la culture médiévale. París: Gallimard, 1972, p. 12.

5. En opinión de D. de Rougemont la dualidad cátara impregna toda la literatura del Occidente medieval. Vid. Denis de Rougemont. L'Amour et l'Occident. París: Plon, 1956, pp. 34, 88 y 157.

6. Gilbert Durand. Les estructures anthropologiques de l'imaginaire. París: Bordas, 1981.

7. Entre otros: espiritual vs corporal, puro vs mancillado, sublime vs vil, sacro vs profano, etc.

8. Como por ejemplo: rico vs pobre, culto vs inculto, alto vs bajo, bello vs feo, etc.

9. Gourevitch. Op. cit., p. 12.

10. Es más, sus poetas lo elogian y convierten en topos recurrente de su poesía. Pensemos en los poetas andaluces como el sevillano Ibn Sâra as-Santarînî, Al-Mu 'tamid, Ar-Rusâfî, Ibn Quzmân y tantos otros, y en los persas Khayyam, Hâfiz o Manoutchehri. Esta temática la hemos trabajado en un artículo que pronto verá la luz: "El imaginario vital y simbólico del vino en los poetas andaluces". 
mesa de vida. Dentro del contexto religioso o sagrado, el vino se convierte en símbolo eucarístico por su transubstanciación en sangre de Cristo, alimento espiritual y bebida de vida eterna. Sobre esto se ha escrito mucho y, dada su complejidad, lo abordaremos en otra ocasión.

Frente a esta visión positiva del vino y del beber por su asociación con la vida y el buen vivir, se alzan las voces de clérigos y moralistas medievales que claman en su contra por sus efectos negativos (la borrachera, la perdida de consciencia, la degradación pública...) y por su consumo en espacios perniciosos como la taberna donde se frecuentan las malas compañías. Esta visión heredada de la concepción negativa, incluso ambigua, que del vino tiene el judaísmo y la Biblia, no tolera demasiado bien el vino por considerar que induce al pecado (embriaguez, lujuria...), y el pecado es siempre la muerte del alma.

Así pues, por su asociación real o metafórica con la muerte o con la cara más oscura y deprimente de la existencia, analizaremos los excesos en el consumo del vino, la abstinencia de vino y el vino en relación con los muertos y los enterramientos. De todo este amplio abanico temático trataremos en el presente estudio, aunque por su amplitud, nos limitaremos a marcar las líneas generales ${ }^{11}$, siendo conscientes de que habrá que volver sobre cada uno de los temas en futuros trabajos, dado su interés.

\section{El vino y la vida}

El vino formaba parte de la alimentación básica en la vida cotidiana del Occidente medieval. Sabemos que se acompañaba con pan y queso cuando la economía era precaria y con carne en las más holgadas. Dejando al margen el agua ${ }^{12}$, el

11. Somos también conscientes de que al elegir las líneas temáticas que, en nuestra opinión, mejor ejemplifican nuestra hipótesis inicial, hemos dejado en el camino otras muchas opciones que contribuyen a mostrar la riqueza e interés de este tema.

12. Por supuesto, la bebida más común es el agua pero siempre que se puede se prefiere el vino y, en su defecto, la cerveza o la sidra. El agua, en general, solía producir desconfianza entre la población por ser foco de infecciones, algunas mortales. Estaba lejos, pues, de ser considerada fuente de salud como lo será el vino. Un testimonio de primera mano en relación con la salubridad del agua nos lo ofrece Le Guide du Pèlerin de Saint-Jacques de Compostelle. En dicha guía se informa al peregrino de los distintos puntos de avituallamiento y se advierte de algunos puntos de España (ej. en Navarra) en los que "coule un fleuve qui donne la mort aux chevaux et aux hommes qui en boivent l'eau" (p.15). Del mismo modo, se nombra a otros ríos cuyas aguas "sont douces et saines à boire", es el caso del Ebro a su paso por Logroño, 
vino es la bebida por excelencia ${ }^{13}$, considerándolo además reconstituyente y hasta curativo, como señala Pastoureau:

Il passe pour une source de santé, un bienfait de l'existence, un don de la nature qui mérite un respect quasi religieux. Aussi la vigne est-elle cultivée partout [...] le long des cours d'eau, dans la banlieue des villes, autour des monastères et des châteaux ${ }^{14}$.

Numerosos son los ejemplos que nos muestran la presencia del vino en la mesa sin importar la clase social. El poeta Eustache Deschamp deja clara su necesidad de comer con vino y hace en su Rondeau profesión de fe de no sentarse a la mesa si éste falta:

\author{
Jamais à table ne serai \\ Si je ne vois le vin tout prêt \\ Pour boire et verser sans arrêt. [...] \\ Au premier morceau telle soif ai \\ Que mort suis, si boire n'y est; \\ Jamais à table ne serai. $[\ldots]^{15}$
}

Lo beben los campesinos y burgueses. Numerosos son los textos literarios que así lo indican, como el fabliau que nos muestra a una burguesa que manda a su criada que prepare la comida para su amigo: "char cuite en pot, pastez au poivre, / Et bon vin cler et sain à boivre"16. El consumo de vino está muy expandido entre las clases populares. Para que nos hagamos una idea, Pierre Delort aporta datos y señala que un trabajador consume aproximadamente unos tres litros diarios de vino (o cerveza), lo que representa unas 1300 calorías ${ }^{17}$. Estas cifras aumentan si hablamos del vino consumido en la mesa de los señores porque el

del Pisuerga, del Carrión, del Mansilla, etc. La dificultad para el peregrino de discernir un agua potable de un agua insalubre era poco menos que imposible, por lo que el autor de la Guía justifica su labor: "Si j'ai décrit ces fleuves, c'est pour que les pèlerins allant à Saint-Jacques se gardent soigneusement de boire les eaux malsaines et puissent choisir celles qui sont bonnes pour eux et pour leurs montures." (p. 17). Le Guide du Pèlerin de Saint-Jacques de Compostelle. Ed. y trad. de Jeanne Vielliard. París: Librairie Philosophique J. Vrin, 1990.

13. Este consumo es seguido a distancia por otras bebidas consideradas populares como la cerveza (también reservada a las mujeres) que se bebe, sobre todo, en las fiestas locales, y la sidra propia de los campesinos.

14. Pastoureau. La vie quotidienne en France et en Angleterre au temps des chevaliers de la Table Ronde. Paris: Hachette, 1976, p. 81.

15. Citado por S. Guermès. Le vin et l'encre. La littérature française et le vin du XIIIe siècle au XXe siècle. Bordeaux: Eds. Mollat, 1995, p. 35.

16. Fabliau Du prestre et de la dame. Los Fabliaux. Edición de Josefa López Alcaraz. Murcia: Servicio de Publicaciones de la Universidad de Murcia, 2003.

17. R. Delort. La vie au Moye-Âge. París: Seuil, col. "Points", 1982, pp. 42-3. 
vino es la bebida de las clases privilegiadas. Sírvanos de ejemplo estas dos novelas artúricas reflejo del mundo aristocrático ${ }^{18}$ :

Erec: "Li rois Artus ne fu pas chiches: bien comanda as penetiers / et as queuz et aus botelliers / qu'il livrassent a grant planté, / [...] et pain et vin et veneison." (vv. 2006-2011) $)^{19}$

L'âtre périlleux: "Pain et vin et car et poison / Oisiax rostis et venison." (vv. 19751976 $)^{20}$

De hecho, los viñedos ocupaban la mayor superficie de los cultivos y cada señor posee en sus tierras grandes extensiones de viñas con las que se asegura la provisión de vino para la casa ${ }^{21}$.

El vino no sólo está presente en las mesas populares, burguesas y aristocráticas, también lo está en las mesas de los hombres de Iglesia y en los monasterios y abadías. La práctica de la religión no está reñida con el vino. Recordemos que durante la Edad Media son los monjes los que entienden de cultivos y, muy especialmente, del cultivo del viñedo y de la elaboración de vino y cerveza. Numerosas y reputadas marcas del mercado actual recuerdan precisamente este origen clerical. Así pues, los monjes entienden de vino y beben vino. A veces beben (y también comen) demasiado siendo objeto por ello de crítica o burla. San Bernardo de Claraval, una de las voces de mayor autoridad en la Iglesia del siglo XII, llama la atención a sus hermanos cluniacenses por sus excesos en la mesa. En su Apología reclama una vuelta a la moderación en el comer y en el beber, lo cual nos ofrece un buen testimonio de la mesa conventual. En esta ocasión nos limitaremos al consumo de vino. Presentamos dos extractos. El primero titulado "Contra tanta superfluidad" (VIII, 16). El segundo "La Bebida" (IX, 21):

18. Como bien ha observado Anita Guerreau-Jalabert ("Aliments symboliques et symbolique de la table dans les roman arthuriens XIIe et XIIIe siècles", in Annales ESC, mai-juin, 1992, n 3, pp. 561-594), el vino junto con el pan y la carne constituyen la triada de alimentos caballerescos mientras que el pescado puede estar o no presente en la mesa: "le poisson n'a pas d'autonomie: il est le complément de la viande, exceptionnellement un substitut, alors que la viande seule ou en association avec le vin suffit à connoter le repas chevaleresque" (p. 563).

19. Chrétien de Troyes. Erec et Enide. Ed. de M. Roques. Paris: Honoré Champion, col. "C.F.M.A.”, 1978. Todas las citas de esta novela remitirán a esta edición.

20. L’Âtre périlleux. Ed. de Brian Woledge. París: Honoré Champion, col. "C.F.M.A.”, 1936.

21. La novela Erec et Enide nos ofrece dos claros ejemplos. Las propiedades que rodean el castillo de Carnant son: "de forez et de praeries, / de vignes, de gaaigneries, [...]" (vv. 2263-4) y las del castillo del rey Evrain se dice son las que convienen a un rico castillo: "et fruiz et blez et vins i vient, / ne bois ne riviere n'i faut" (vv. 5351-5353). 
A mí no me entra en la cabeza, por otra parte, que llegaran a legislar o condescender con tanta cosa inútil o superflua como veo en muchos monasterios. No me explico cómo pudo arraigar semejante inmoderación entre los monjes a la hora de comer y de beber (VIII, 16)

No puedo sugerir que nos contentemos con beber agua, cuando ni siquiera soportamos beber el vino mezclado con agua. Porque todos sin excepción, en cuanto nos hicimos monjes, por lo visto comenzamos a padecer del estómago, a juzgar por nuestra fidelidad en cumplir el consejo tan oportuno del Apóstol (Pablo) acerca del vino. Pero no sé por qué nos olvidamos el adverbio con que matiza su frase: módicamente. [...] Cuando te sientes a la mesa, podrás observa cómo un monje devuelve tres o cuatro tazas medio llenas, después de haber olfateado diversos vinos sin beberlos, pero probados ya casi sin rozarles los labios, como un consumado catador que con experta rapidez elige al fin el más fuerte y exquisito. Los días de solemnidad ha llegado a imponerse en algunos monasterios la costumbre de beber en el refectorio vinos rociados de miel y espolvoreados con especias. ¿También esto lo hacen por debilidad de estómago? Seamos sinceros; se trata solamente de poder beberlo en abundancia y paladearlo con mayor deleite. (IX, 21) ${ }^{22}$

Como hemos mostrado, el vino es indispensable en la mesa medieval, pero además forma parte de la vida en los momentos más alegres. Pensemos en los festines y convites, imágenes en las que el anfitrión busca agasajar con las mejores viandas y vinos a sus invitados. No olvidemos que la ostentación de la comida y de la bebida, así como el pecado de "gula", se convierten en distintivos de poder económico y también de clase señorial. A este respecto señala Le Goff: “L'alimentation est la première occasion pour les couches dominantes de la société de manifester leur supériorité dans ce domaine essentiel du paraître. Le luxe alimentarie est le premier luxe"23. Y verdaderamente se bebía mucho y también se comía mucho. En una época en la que la bonanza alimentaria es precaria y el miedo al hambre acecha ${ }^{24}$, el comer y el beber para mantener la vida se convierte en obsesión colectiva que cristaliza en numerosas imágenes (como el país de Cocagne) ${ }^{25}$ y personajes como Gargantúa. En la literatura medieval son numerosos los pasa-

22. Bernardo de Claraval. Obras Completas. Edición de los Monjes Cistercienses de España. Madrid: Biblioteca de Autores Cristianos (BAC), 1993.

23. J. Le Goff. La civilisation de l'Occident médiéval. París: Flammarion, col. "Champs". 1982, pp. 328 y 329.

24. El miedo a las hambrunas y a lo que éstas acarrean es un miedo que siempre está presente. Esto explica suficientemente esta obsesión por comer y beber. "La vie de l'Occident est donc rythmée par ces famines qui, sans toujours provoquer la mort, favorisent au sein de la population sous-alimentée d'épouventables épidémies qui massacrent d'abord les faibles (femmes, enfants, vieillards, pauvres) avant de s'attaquer aux forts, aux puissants, aux riches". (Delort. Op. cit., 47).

25. El mismo tema literario se encuentra en la literatura española con el "país de Cucaña", lo que demuestra que esta quimera tiene una base común: el hambre que espolea el consciente colectivo medieval. 
jes en los que se mencionan grandes festines. Célebres son los del rey Arturo cuando congrega en torno a su mesa a todos los caballeros, damas y doncellas de su reino. Pero si la literatura artúrica es parca en la descripción de las viandas, contamos con otros documentos que se explayan sobre este tema describiendo ricos festines como el que ofrece el fabliau Du prestre e du chevalier, en el que el «prestre» ofrece lo mejor de su cocina al caballero creyendo, eso sí, que se le retribuirá. Lo traemos a colación para dar una idea precisa de la abundancia y diversidad de estas copiosas comidas ${ }^{26}$ :

\author{
Les servi on. I. à un mès. \\ Et, devant tous les autres mès \\ Fu premiers li pains et li vins. \\ Li chars de porc et li connins ... \\ Celle viande doit bien plaire. \\ Après orent oisiaus nouviaus; \\ Puis fu aportés li gastiaus, \\ Et li capon furent su soivre, \\ Et li poisson à le fort poivre, \\ Et les pastés à déerains $[\ldots]$
}

\author{
Et kanièle, si com je cuit, \\ Dame Avinée, qui fu lie, \\ Aporta nois et autre fruit, \\ Et Kanièle, si com je cuit, \\ Et gyngembras et ricolisse; \\ Mainte boine herbe et mainte espise \\ Lors aporta dame Avinée. \\ [...] Et burent vin, vermeil et blanc, \\ Cler comme larme, et pur, et franc, \\ Assés et as grans alenées.
}

La hospitalidad es la regla de oro de las relaciones sociales. Ofrecer y compartir comida y /o hospedaje es adecuarse, en la sociedad medieval, a los códigos de conducta dominantes, además de ser en muchas ocasiones un signum de opulencia del anfitrión, y un deber de buen cristiano (la caritas) con los que lo necesitan. No ser hospitalario supone ir a contrario, declararse anti-social en una época en la que el individuo adquiere su valor e identidad al formar parte de un todo social. Por lo tanto, lo adecuado es ofrecer tu mesa y tu casa, y comer y beber en compañía. Raros son los ejemplos en los que los textos nos presentan a un personaje bebiendo y comiendo solo, porque la comida en compañía está ligada a la conversación, al intercambio de opiniones para darse a conocer y conocer al otro. Anita Guerreau-Jalabert muestra en su estudio cómo la palabra y el alimento son medios equivalentes de comunicación social ${ }^{27}$.

En resumen, todo es poco para honrar y agasajar a un invitado, y el vino nunca falta en la mesa. Poco importa que el anfitrión tenga pocos recursos económicos como es el caso de las serranas que en el Libro del Buen Amor ofrecen vino al viajero: "Darte he del pan e del vino" dice la serrana de Malangosto (965) y el viajero confir-

26. Du prestre et du chevalier. Ed. cit., pp. 124-125. Advertimos que de esta pormenorizada descripción sólo se han utilizado los versos que convenían a la imagen que queremos ofrecer de festín opulento.

27. Op. cit., p. 575. 
ma "Dióme ... de buen vino un quartero" (968-9) $)^{28}$, o que sean ricos o/y señores. En este caso, el vino corre en abundancia. En la Deuxième Continuation de Perceval se menciona que había "Et pain, et char fresche, et poisson, / et vin asses et a foisson"29.

El vino se alía, también, con la vida por sus virtudes reconstituyentes y curativas. Se tiene la opinión general de que es beneficioso para el cuerpo si se bebe con moderación y un remedio activo en la sanación solo o combinado con otros ingredientes para obtener pócimas y recetas.

Efectivamente, el vino es un reconstituyente eficaz para reanimar las fuerzas y dar calor a los cuerpos ateridos de aquellos que andan por los caminos, ya sean caballeros andantes, guerreros que van o vienen del campo de batalla, peregrinos en medio de su larga andadura o bohemios (poetas, juglares, malabaristas, cómicos...) que recorren los caminos en busca de clientela y acomodo. Para todos ellos se articula el mismo sueño: encontrarse al abrigo, bajo un techo caliente, bebiendo un buen vino que les estimule el cuerpo y el alma. Veamos algunos ejemplos.

Los caballeros andantes en la novela y los guerreros en la realidad histórica a veces beben vino antes de la batalla o del torneo ${ }^{30}$ para infundirse ánimo ( $\mathrm{La}$ Mort du Roi Arthur, vv. 2005-68) ${ }^{31}$, y beben después para reponer fuerzas. Este es el caso de Bertrand de Born, un trovador occitano y señor feudal que en pleno invierno vuelve con su hueste del campo de batalla y añora, como dice en su canción Ges de disnar no fora oi mais matis, "un buen albergue con fuego de haya" para calentarse y "carne, pan y vino"32: la carne aporta proteínas, el vino renforce la chaleur naturelle y el pan transforma los hidratos de carbono en azúcares, de modo que los tres alimentos evocados aportan la energía necesaria para que los caballeros recuperen sus fuerzas.

28. Juan Ruiz Arciprestre de Hita. Libro del Buen Amor. Ed. Alberto Blecua. Madrid: Cátedra, 1992.

29. Deuxième Continuation de Perceval. Ed. De W. Roach, t. IV. Filadelfia. vv. 25.195-25.196.

30. Este tema fue tratado en mi estudio "La cultura del vino en la Edad Media. Presencia y función del vino en la narrativa caballeresca” in Angles Santa y Cristina Solé (eds.). Texto y Sociedad en las letras francesas y francófonas. Lérida: Universidad de Lérida, 2009, pp. 57-68.

31. La Mort du roi Arthur. Ed. de M. Santucci. Paris: Honoré Champion, col. “C.F.M.A.”, 2005. Otro ejemplo que traemos a colación hace referencia a Le Beau Inconnu. Éste y sus acompañantes han vencido a unos terribles gigantes, después han podido saciar su sed y su hambre con “... trente pains / [...] Janbes salees, oissialz ras, / Tos rotis et tos atornés; / De bon vin ont trové asés. (Renaut de Beaujeu. Le Bel Inconnu. Ed. de G. Perrie Williams. Paris: Honoré Champion, col. “C.F.M.A.”, 1983, vv.: 901-06.

32. "(I) Ges de disnar no fora oi mais matis /qui agues pres bon ostau, / e fos didintz la charns e' 1 pas e' 1 vis, / e'l fuocsfos clars com de fau". Martín de Riquer. Ed.cit., p. 693. 
Cierto es que aquellos que soportan la dureza del camino son los más necesitados, pero cierto es también que el propio camino otorga tanto como quita equilibrando la balanza de la necesidad. Es el caso de Erec y Enide que, agotados tras su mal encuentro con los cinco caballeros ladrones y tras pasar la noche en el bosque, se encuentran a la mañana siguiente, hacia el mediodía, con un escudero acompañado por dos criados que llevan pan, "buen vino" y cinco quesos cremosos. El escudero adivinando su necesidad les ofrece su comida de la que comen con apetito: "le gastel et le vin lor baille, / un fromage lor pere et taille; / cil mangierent qui fain avoient, / et del vin volantiers bevoien;" (3167-3170).

El frío y el camino van parejos en el imaginario medieval, de modo que no puede extrañar que sea un tema recurrente en la poesía goliárdica. Ambas imágenes suscitan con frecuencia la añoranza de un buen fuego y una jarra de vino: “[...] y llenad bien los vasos de buen vino. Cuando haga frío sentaos a buen rescoldo con un jarro de buen vino en vuestras manos..." ${ }^{33}$.

También en las rutas de peregrinación el cansancio, el hambre y la sed hacen mella en los viajeros. Para paliar estas vicisitudes surgen las Guías que informan y aconsejan a los peregrinos sobre hospedajes y, lo más importante, sobre dónde comer y beber. Veamos algunas indicaciones ofrecidas en Le Guide du Pèlerin de Saint Jacques de Compostelle; en todas ellas se hace constar el vino y otras viandas necesarias para hacer frente al camino:

- "Estella où le pain est bon, le vin excellent, la viande et le poisson abondants et qui regorge de toutes délices" (p. 7).

- "Carrión, qui est une ville industrieuse et prospère, riche en pain, en vin, en viande et en toutes sortes de choses" (p. 7).

- "La Castille et sa campagne [...] ce pays produit heureusement du fourrage et des chevaux vigoureux, et le pain, le vin, la viande, les poissons, le lait et le miel y abondent." (33).

Por el contrario:

- Les Landes bordelaises [...] c'est un pays désolé, où il n'y a ni pain ni vin, ni viande, ni poisson, ni eau, ni sources..." (p. 19).

El vino es considerado fuente de salud siempre y cuando se beba con moderación ("Es el vino muy bueno en su mesura natura / muchas bondades tiene si

33. Saludo a los de Galia: "tempus cum sit frigidum ad prunas sedete; vinum meracissimum manibus tenete; calices si fuerint vacui, replete; ut bibat et revibat saepe suadete". R. Arias. La poesía de los goliardos. Madrid: Gredos, 1970, 248-9. 
s'toma con mesura"34) y preferiblemente en las comidas, entonces sus efectos son reparadores, como señala Franco Cardini ${ }^{35}$.

Esta regla de oro de su consumo, extensible a la comida, es la recomendación constante de sabios y pedagogos. En Le Secret des Secrets Aristóteles la inculca en Alejandro ${ }^{36}$, y la madre de Jehan de Saintré, en el pequeño Jehan: "On doit seulement mangier et boire pour vivre et non pas vivre pour boire et pour mangier, comme les gens pourceaux font" ${ }^{37}$.

El vino rebajado con agua pierde el exceso de fuerza por lo que es recomendado para los enfermos y convalecientes. Guivret le ofrece un vaso de este vino mezclado a Erec que yace malherido de su último combate. Esta es la explicación que el propio Guivret le da al enfermo:

Vin a eve meslé bevroiz;

J'en ai de boen set barrilz plains,

Mes li purs ne vos est pas sanins,

Car bleciez estes et plaiez.

[...] li purs li estoit trop rades.

[...] Erec manja come malades

et but petit, que il n'osa; (Erec: 5108-1127)

Un ejemplo similar lo ofrece el Libro Enfendido de Don Juan Manuel: el infante recomienda, siguiendo los dictámenes de los físicos, una alimentación basada en "pan et vino et carne, con los menos adobes que pudiéredes". Además, "la meatad de vino et la meatad de agua" para rebajarlo ${ }^{38}$.

Por otra parte, el vino es reconocido desde la Antigüedad por sus virtudes curativas $^{39}$. Bebido o de uso externo (por ej. para curar o ablandar el flemón). Puro

34. Gonzalo de Berceo. Obra Completa. Ed. crítica de B. Dutton. Madrid: Espasa-Calpe,1992, 548, a, b.

35. F. Cardini. "Hoc est sanguis meus. Le vin dans l'Occident médiéval" in Le Ferment Divin. Paris: Éditions de la Maison des Sciences de l'homme, 1991, p. 101.

36. Secret des Secrets (o Secretum Secretorum) es un tratado medieval pseudo-aristotélico al estilo del "Miroir des princes" en el que Aristóteles escribe una carta a su discípulo macedonio, Alejandro Magno, para instruirle en temas heteroclitos como la moral, la política, la alquimia, la astrología, etc. Una de las partes del Secret se titula "De regimine sanitatis", es decir, "De la higiene del cuerpo". A ella pertenece nuestra referencia.

37. Antoine de La Salle. Jehan de Saintré. Ed. de J. Misrahi et Ch. A. Knudson. Ginebra: Droz, 1967, (25, 122$)$.

38. Don Juan Manuel. Obras Completas. Ed. de José Ma Blecua. Madrid: Gredos, 1981, t. I, pp. 153-6.

39. Jean-Marie André. "Vertu thérapeutique du vin et pathologie de l'ivresse à Rome, de Lucrèce à Pline l'ancien" in Actes du XXe Congrès Les Ecrivains et le Sacré. La vigne et le vin dans la littérature. 2eme partie. París: Les Belles Lettres, 1989, pp. 450-2. 
o mezclado con otros ingredientes es la base de muchas recetas por sus propiedades diversas ${ }^{40}$. En el Compendio de la Humana Salud del médico vienés (s. XV) Iohannes de Kethan, se aconseja el vino para numerosos remedios:

[...] en septiembre son muy buenas las peras con vino, en octubre es saludable el buen vino, en noviembre el vino melado; para evitar la impotencia es recomendable cocer los riñones del ciervo en vino, que sea muy bueno, del cual beberás cuando sea necesario, Y verás maravillas. Para purgar la matriz, toma perejil o su zumo mezclado con vino... o toma la raíz de las violas con las hojas, cuécelas bien con cerveza o con vino..." ${ }^{\prime 4}$.

Dada la amplitud del tema de los efectos medicinales del vino, nos limitaremos aquí a ofrecer algunos ejemplos que muestren la creencia generaliza en este valor curativo del vino. En la Biblia, San Pablo escribe en su Epístola a Timoteo (I, 23): "No bebas ya agua sola. Toma un poco de vino a causa de tu estómago y de sus frecuentes indisposiciones". En la Vida de Santo Domingo de Berceo, el santo ofrece el vino caliente con su bendición a una enferma para curarla: "Assí commo lo ovo de la boca passado, / la duenna fó guarida, el dolor amansado, / salló fuera del lecho..." (307, a, b, c, d) ${ }^{42}$. En el Secret des Secrets, en "De la première partie du corps (LV)", el vino está presente en una receta contra "los malos humores" que se concentran en la cabeza. Henri Pérès en su obra Esplendor del Al-Andalus ${ }^{43}$ recoge que "Abu 'Amir Ibn al-Faray cuida de su hijo aquejado de una enfermedad del hígado con vino añejo". También el vino puede ser un remedio para que las embarazadas engendren hijos varones: "el pan con que comieren ha de ser candial, hecho de flor de harina, [...] La bebida ha de ser vino blanco aguado en la proporción que el estómago lo aprobare"44. Y por supuesto, todas las virtudes que le atribuyen al vino los buenos bebedores que lo consumen.

40. Vid. M ${ }^{\mathrm{a}}$ Teresa Herrera. Tratado de las apostemas de Diego El covo. Salamanca: Universidad de Salamanca, 1983, p. 40.

41. Iohannes de Ketham. Compendio de la Humana Salud. Estudio y edición de María Teresa Herrera. Madrid, 1990. Citado por José Luis Martín Rodríguez, El vino y la buena mesa medieval. Logroño: Universidad Nacional de Educación a Distancia (UNED), Rioja, 1998.

42. Berceo, Vida de Santo Domingo. Ed. cit.

43. H. Pérès. Esplendor de al-Andalus. Madrid: Hiperión, 1990, p. 369, n. 34.

44. Examen de ingenios para las ciencias de Huarte de San Juan. Citado por Ma Rosa Nadales. "La mujer y el vino en la literatura: Historia de un desencuentro, Boletín de la Real Academia de Córdoba de Ciencias, Bellas Artes y Nobles Artes, n 146, 2004, pp. 321-4 (p. 322). 


\section{El vino y la muerte}

Este apartado se configura como antitético del anterior, por lo tanto, en él analizaremos los temas del vino asociados con la enfermedad, el pecado y la muerte, es decir, imágenes de decadencia física y espiritual, que no siempre se acompañan de sufrimiento y oscuridad, dado que nos encontramos en una época en la que se disfruta plenamente el carnaval con su mundo al revés, y la vida se cuela por las rendijas de la muerte abriendo la puerta a otra forma de existencia. Por otra parte, hemos considerado oportuno introducir en este apartado la abstinencia de vino, una ausencia que se opone de manera significativa a su recurrente presencia en la mesa medieval, como ya hemos mostrado en el apartado anterior.

La abstinencia de vino aparece muy ligada en la época al universo religioso a través de sus preceptos como, por ejemplo, el abstenerse de comer carne y también vino en Cuaresma y durante los viernes del año ${ }^{45}$. En estos casos, el régimen alimenticio se basa en el triángulo pan-pescado-agua, siendo el pescado el substituto de la carne y el agua del vino.

Una renuncia que se fundamenta en el sacrificio: se mortifica la carne renunciando a sus placeres como medio de purificación. La abstinencia suele acompañarse con el ayuno ("contre la chair, l'arme suprême est le jeûne", rezan los manuales penitenciales), otra forma de sacrificio igualmente costosa de cumplir para una sociedad que hace del comer y del beber su aspiración más legítima.

Renuncia, sacrificio, mortificación, conceptos éstos que remiten a la anulación de lo corporal, sentido como rémora que lastra el alma (muerte simbólica), para alcanzar la vida espiritual. Numerosos son los pasajes literarios que nos remiten a este contexto. Quizá uno de los más importantes lo encontramos en Le Conte du Graal de Chrétien de Toyes. Esta obra impregnada de misticismo cristiano ha ejercido una influencia decisiva en el Occidente cristiano y generado un mito que llega hasta nuestros días. El pasaje al que nos referimos nos presenta a Perceval visitando al ermitaño del bosque para confesar, el día de Viernes Santo, sus pecados ${ }^{46}$ y hacer penitencia y oración.

45. Vid. El espéculo de los legos. Ed. de José $\mathrm{M}^{\mathrm{a}}$ Mohedano. Madrid: Consejo Superior de Investigaciones Científicas, 1951. Esta obra escrita en latín (Speculum Laicorum) y compilada en la Inglaterra del siglo XIII es una colección de ejemplos o anécdotas del campo de la predicación medieval.

46. Desde que abandonó a su madre causándole por este dolor la muerte, Perceval ha vivido durante años alejado de Dios y de la Iglesia. 


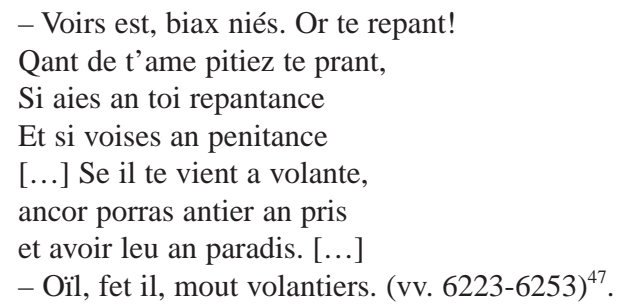

Con la aceptación de Perceval da comienzo su proceso expiatorio fundamentado en el ayuno y una alimentación penitencial que compartirá con el ermitaño (avoec moi ici te remaignes / et que an penitance praignes / tel viande ${ }^{48}$ come la moie" (vv. 6255-7), consistente en "cerfuel, leitues et cresson" ("perifollo, lechuga y berros'), "et pain i ot d'orge et d'avainne" ('pan de cebada y de avena'), "et eve clere de fontaine" ('agua clara de la fuente') ${ }^{49}$. Cuando termina su purificación, Perceval es un ser regenerado espiritualmente con una meta transcendente en su vida: la búsqueda del Santo Grial.

Esta alimentación pobre a base de hortalizas, pan tosco hecho con los cereales que son el forraje de los animales, y agua de la fuente ${ }^{50}$ constituye el régimen o triángulo alimentario (pan-agua-vegetales) de los eremitas. Es decir, de todos aquéllos que eligen voluntariamente seguir en solitario una vida de privaciones y sacrificios (renuncia al confort, a la buena alimentación, etc.) en bosques y parajes desérticos. La novela artúrica está llena de estos ermitaños que, a pesar de su miserable vida, acogen siempre de buen grado a los caballeros haciéndoles partícipes de su precaria dieta. Este es el caso del ermitaño de Perceval y de otros muchos que siguen esta constante, incluso en alguno se hace hincapié en la ausencia de vino. Veamos otros ejemplos:

Yvain: "de son pain et de sa porrete / para charité prist li boens hom... / de l'eve froide but au pot" (vv. 2840-1, 2854) ${ }^{51}$.

47. Chrétien de Troyes. Le conte du Graal (Perceval). T. I: ed. de Félix Lecoy. París: Honoré Champion, col. "CFMA", 1979; T. II: ed. de Félix Lecoy. París, Honoré Champion, col. "CFMA”, 1984. Citaremos por esta edición, salvo mención expresa.

48. El término "viande" tomado en sentido genérico significa "comida" o "alimento".

49. Para la descripción de la comida hemos adoptado la variante de la edición Hilka (vv. 279-82), ya que la copia de Guiot no la especifica.

50. Los ritos penitenciales más severos reducen la alimentación a pan y agua, tal y como se recoge en los manuales de la confesión en la Francia medieval. Sobre este tema remitimos a J.-C. Payen. Le motif du repentir dans la littérature française médiévale. Des origines à 1.230. Ginebra: Droz, 1968.

51. Chrétien de Troyes. Le Chevalier au lion (Yvain). Ed. de Mario Roques. París: Honoré Champion, col. "CFMA", 1982. 


\section{La continuation de Perceval (Gerbert de Montreuil):}

1. "Pain d'orge et Fontaine et cresson / Apporte por desjeüner" (vv. 7392-3) ${ }^{52}$.

2. "Pain d'orge a leschive pestri; [...] / erbes, laitues et cresson / i ot, et menu fruit salvage / qui fu coillis par le boschage; / mais il n'i ot claré ne vin, / ainz but de l'iaue a un bachin" (vv. 15774-15782).

Estos ermitaños no sólo alimentan al necesitado, también lo reconducen por la buena senda espiritual aliviando sus pecados. Todos los pecados, y más si los comenten los príncipes, gobernantes o clérigos, son duramente atacados por la Iglesia desde los púlpitos y a través de su doctrina. El de embriaguez es uno de los más frecuentes y contra él claman moralistas como Jacques de Cessoles en su obra Le Jeu des Eschaz moralisé que viene a ser un resumen de los Miroirs des Princes de los siglos XI-XIII, o el franciscano Francesc Eiximenis que considera la embriaguez "un vicio mortal" cuando se cae en él por propia voluntad y plena consciencia ${ }^{53}$.

En líneas generales, la Iglesia no condena el vino siempre que se beba con moderación ${ }^{54}$, incluso se le reconoce efectos beneficiosos para el cuerpo y para las relaciones sociales (contribuye a la alegría general, a la convivencia, etc.). Sin embargo, con frecuencia ciertos clérigos y moralistas mantienen una postura ambigua respecto al vino que tiene su origen en los ejemplos a favor o en contra que aporta la Biblia (El ejemplo negativo más reiterado es el de Noé. En su valoración positiva se dice que la Tierra Prometida es "un país de viñedos y olivares ${ }^{55}$ ).

En una sociedad tan permeable como la medieval, la ambigüedad religiosa en torno al vino pronto se refleja en la literatura, sobre todo, la de los siglos XII y XIII en los que el imaginario del vino desarrolla toda su riqueza ${ }^{56}$. Jean Dufournet defiende la existencia en pleno siglo XIII de dos escuelas literarias que desa-

52. Gerbert de Montreuil, La Continuation de Perceval, T I y II. Ed. de M. Williams. París: Honoré Champion, col. "CFMA", 1922-25. T. III ed. de M. Oswald, 1975.

53. En su libro Lo Chrestià, que gozó de gran prestigio en su época, Eiximenis (s. XIII) deriva el pecado de embriaguez del pecado capital de la gula que, en su opinión, es la fuente de todos los pecados y el comienzo de la muerte del alma. La gula junto con la pereza y la lujuria constituyen los pecados de la carne en oposición a los del espíritu (soberbia, avaricia, ira y envidia). Vid. E. Juncosa. "Vinum et ebrietas auferun cor". La condena moral por embriaguez según Francesc Eisimenis", in Pecar en la Edad Media. Coords. Ana Isabel Carrasco y Ma Pilar Rábade. Madrid: Silex, 2008, pp. 263-278.

54. Ya hemos señalado con anterioridad como el vino es la bebida cotidiana de los religiosos seglares y regulares.

55. Amós, 9-14. La imagen de la viña es utilizada en la Biblia para simbolizar la elección de Israel por Yahvé.

56. En la primera parte de este artículo hemos ofrecido ejemplos positivos de esta polémica a cerca del vino. Vid. supra. 
rrollan la temática enológica, la de Arras que sigue la línea de Jean Bodel de exaltación alegre del vino y del beber y la de París de componente más clerical que desarrolla la temática desde la alegría, la crítica y los debates. Figuras conocidas se asocian con estas dos escuelas: el ya citado Jean Bodel, también Jean le Teinturier y Henri d'Andeli, entre otros.

Pero con más frecuencia aún observamos cómo la ambigüedad de los clérigos da paso a la condena tajante del vino y del beber, por la "alienación" que produce en el ser humano, olvidando la rehabilitación que del mismo introducen los Nuevos Evangelios en las Bodas de Cana y La última Cena ${ }^{57}$, y desoyendo voces destacadas de la Iglesia como la de Tomás de Aquino, uno de los teólogos más importantes de la Edad Media que se muestra favorable al vino y lo defiende en algunos de sus aspectos.

Esta reacción moralista se percibe en la literatura a partir del siglo XIV, como prueba la proliferación de la literatura didáctica (dits, exempla) en la que el tema del vino se silencia o es atacado. Un ejemplo de esto último aparece en Le Dit des Ivrognes de Jean Auri (s. XIV), que al estilo de aquellos escritos que celebran los milagros del vino, éste sirviéndose de la antífrasis insiste, en cambio, en los efectos negativos del vino ("saint Tortu" o saint Tortuel") en jóvenes, mujeres y viejos. Como el dit es algo extenso, nos limitaremos a mostrar aquí algunos de sus pasajes.

(1) Je vous dirai comment

On voit très clairement

Les miracles et les vertus

Que fait Messier saint Tortu. [...]

Quant un homme est en grand malheur,

Si saint Tortu entre dans sa tête,

Il lui dissipe ses soucis. [...]

Saint Tortuel est si puissant

Qu'il fait revenir un vieillard

(3) L'un regarde vers le ciel:

S'il voit venir sur son sourcil

Un cheveu, alors il enrage;

Il croit que c'est une araignée

Qui veut lui crever les yeux. [...]
(2) En enfance et penser des folies.

Et il rend aussi mainte femme joyeuse:

Quand elle a baisé saint Tortu [...]

Alors, elle veut danser et sauter

Et bien souvent rêver ailleurs

À Vieux ou à jeune homme.

Saint Tortu ne peut se cacher.

Il y a tant de sortes d'ivrognes

Qu'on en pourrait faire un gran livre: [...]

(4) On voit très souvent le cas

D'un autre, si désorienté

Qu'une chose lui semble trois.

Un autre veut toujours i plaider,

Mais sa langue ne peut l'aider... ${ }^{58}$

57. En opinión de A. Corbellari, la revalorización del vino, aunque evidente, no es total. El vino aparece ligado a la condición terrestre del ser humano pues su color lo convierte en "analogon" de la sangre, substancia vital del cuerpo que se opone a la transparencia casi "inmaterial" del agua, por lo que vemos de nuevo la oposición cuerpo vs alma. Vid. Alain Corbellari. La voix des clercs. Littérature et savoir universitaire autour des dits du XIIIe siècle. Ginebra: Droz, 2005, pp. 119-120.

58. Jean Auri, Le dit des ivrognes. Ed. y trad. en francés moderno por S. Guermès. Le vin et l'encre. Op. cit., pp. 36-9. 
De todos modos, y a pesar de la ironía, la ambigüedad emerge en el corazón de la crítica y el dit se cierra señalando que, auque el vino juega malas pasadas, también ayuda a hacer amistades y cerrar negocios.

C'est le vin qui scella la réconciliation.

Seigneurs, vous pouvez bien le croire:

Boire fait commettre maint vilain tour,

Et cependant il arrive

Qu'en buvant on fasse un marché

Propre à satisfaire maint prud'homme.

C'est ce dont témoigne Jean Auri ${ }^{59}$.

La sociedad, por su parte, se hace eco de esta condena a la embriaguez, un pecado vinculado a lo social porque, como ya hemos comentado, no hay costumbre de beber solo. Beber vino en distintas ocasiones forma parte de lo establecido y admitido, pero beber hasta la embriaguez es uno de los pecados más comunes entre los hombres del medievo y genera escándalo y rechazo en el tejido social, sobre todo, por las secuelas que arrastra que no sólo afectan al individuo que bebe, sino a toda la comunidad. Por ello, se crítica fuertemente al borracho (Quid turpius ebrioso: ‘qué hay más despreciable que un borracho?') como hace el trovador Manfredo I Lancia, marqués de Busca, que se burla de las fanfarronadas y de la lengua sin freno ${ }^{60}$ del trovador Peire Vidal, llamándolo emperador y tildándole de borracho:

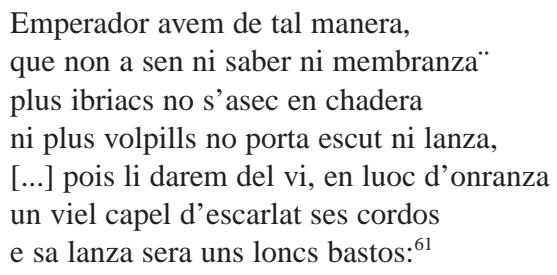

Las borracheras se propician en reuniones familiares, convites, festines y fiestas. etc. En las ciudades el espacio lúdico por excelencia es la taberna en la que se reúnen los hombres para beber, charlar y jugar. Las tabernas siempre fue-

59. Ibid. pp. 38 y 39 .

60. Uno de los efectos del vino es que "desata la lengua" y generalmente para mal. En una pequeña composición de la poesía de goliardos, Hircus quando bibit ('El vino locuaz'), se habla de ello: "Cuando un lujurioso bebe, dice lo que no debe; cuando bebe mucho, habla más de lo debido" ("Hircus quando bibit, / que non sunt debita dicit, / cum bene potatur, / que non sunt debita fatur". (Arias. Op. cit., pp. 230-1).

61. Trad. de M. de Riquer: "Tenemos emperador [...] ninguno más borracho se sentó en trono, ni más cobarde llevó escudo y lanza [...] luego, en lugar de honor, le daremos vino, un viejo sombrero de escarlata sin cordones y su lanza será un grueso bastón”. Ed. cit., T. II, p. 859. 
ron mal vistas por la Iglesia por ser lugares de vicio, lo mismo que los lupanares o casas de prostitución.

Los moralistas tenían ideas claras y poco benévolas a propósito de la taberna y prohibían a los clérigos que las frecuentaran. Durante la era preindustrial la taberna se configuró como la anti-Iglesia. En 1413, san Vicente Ferrer recomendaba que se cerrasen las tabernas los domingos, durante los oficios, por ser los lugares de las tentaciones y de los múltiples pecados ${ }^{62}$.

Tabernas y prostíbulos son los espacios de exclusión o marginación sociales en el Occidente medieval ${ }^{63}$, aunque de nuevo vemos que se toleran como mal menor $^{64}$. A La taberna se alude como lugar de encuentro ${ }^{65}$ donde compartir con los compadres una jarra de vino y disfrutar de momentos de alegría en los buenos tiempos, o de emborracharse en los malos para olvidar el aciago destino ${ }^{66}$. Por eso, para los amantes del vino y de la taberna su ausencia es causa de enojo como expresa el trovador Monje de Montaudon en su más famoso "enueg” cuando canta: "Et enoiam, per vita eterna, [...] / e jaser ab veill'a galerna, /quan m'en ven flairors de taverna;" (V) ${ }^{67}$; es decir, "Y me molesta, ... estar en vela a la intemperie cuando me llegan olores de taberna...' (V). Pero la taberna es considerada por muchos fuente de conflicto dado que se fomentan las peleas y se corre el riesgo de perder los bienes en vino y juego provocando la ruina social y económica. Hay quienes lo pierden todo, hasta la ropa que llevan puesta. Esto es lo que le sucede

62. María Asenjo González. "Integración y exclusión. Vicios y pecados en la convivencia urbana", in Pecar en la Edad Media. Op. cit., pp. 185-207 (p. 199).

63. Los hospederos, los juglares y trovadores, los taberneros y las prostitutas eran considerados, entre otros muchos, gente de mal vivir y sus oficios viles y despreciables, es decir, "in honesta mercimonia" o "vilia officia". Desde este planteamiento, la taberna era considerada un antro de perdición, un lugar en el que los asiduos podían caer fácilmente en el vicio, ya fuera de lujuria, de embriaguez o de juego. En el trasfondo de esta reprobación de la mayoría de los oficios urbanos (artesanos y mercantiles) se encuentra la supervivencia de numerosos tabúes que ejercen todo su poder en las sociedades primitivas como la medieval. (Cf. Le Goff. Pour un autre Moyen Âge. Temps, travail et culture en Occident. París: Gallimard, col. "Bibliothèque des Histoires", pp. 92- 93). Remitimos a la misma obra para consultar la lista de los trabajos considerados serviles y de los que no pueden realizarse en domingo (pp. 91 y ss.). Una muestra del rechazo a esta denominada escoria social nos lo ofrece el trovador Marcabru en una de sus poesías más famosas: Pax in nomine Domini.

64. Remitimos sobre este tema al artículo de María Asenjo González, art. cit.

65. Los goliardos (poetas latino-medievales) y los poetas andalusís del al-Andalus hacen de la taberna el tema central de muchas de sus composiciones. Para muchos de ellos es el lugar donde sentarse con los amigos para charlar y beber hasta la embriaguez o, en el caso de la exquisita sensibilidad de algunos poetas andaluces, vivir un momento pleno en comunión con naturaleza y con uno mismo.

66. La embriaguez se suele acompañar de un estado de disolución de la consciencia, lo que permitiría escapar a las voces de los moralistas que restañan en las conciencias de los hombres. El vino y la embriaguez tienen como función abolir la condición cotidiana de la existencia. Vid. Durand. Op. cit., pp. 48 y 49.

67. Riquer, Op. cit., t. III, p. 1028. 
al trovador Guilhem Magret. Su afición al vino y a la taberna anda en boca de sus compañeros que arremeten contra él sus críticas en algunas de sus composiciones, como la de Guilhem Rainol d'At: Maget, pujat m'es el cap:

I Magret, [...] si no us sap, Pres del vaysselh ab l'enap; Qu'ades tendetz vostre trap Lai on sentetz la taverna ${ }^{68}$.

V Adug vos an a derroc, Magret, dat, putans e broc ${ }^{69}$

VII Magret, ben saup selh que val mais odors de broc contra sabor de sisterna ${ }^{70}$.

La decadencia social y económica del gran bebedor suele ir pareja con su ruina física. La literatura medieval se hace eco por doquier de los efectos negativos del abuso de vino. Dichos efectos se observan tanto en lo corporal como en lo espiritual. Los hombres de Iglesia denuncian que el exceso de vino estimula la lujuria y alienta la infidelidad. Como señala Josep Hernando en su excelente artículo "Els moralistes i l'alimentació a la baixa Edat Mitjana": "els moralistes insisteixen, sobretot, en la relació, de causa i efecte, amb els desordres sexuals, la luxuria":

Ventrem distentum cibis et vini potationibus irrigatum, voluptas luxuriae sequitur, ebrietas fomentum libidinis, ebrietas sigillum castitatis frangit, fornicationes ex eo sunt, fugiamus ebrietatem ne in retia luxuriae incurramus, nutrit flamman fornicationis, concitat libidinem, luxuriam facit et nutrit vini perceptio nimia, nam natura vinum et adolescentia duplex est incendium voluptatis ${ }^{71}$.

Por supuesto, en el imaginario patriarcal, la ebriedad en la mujer es la peor de todas, pues la combinación mujer-vino hace de ésta un ser todavía más peligroso y perverso. Por ello es criticada en numerosos escritos y refranes, incluso

68. Trad. I: "Magret... pero quien bien os busca y os persigue os puede encontrar, si no sabe dónde estáis, cerca del tonel con el vaso; porque siempre montáis vuestra tienda de campaña allí donde oléis la taberna".

69. Trad. V: "Magret, os han llevado a la ruina los dados, las putas y la jarra...".

70. Trad. VII: "Magret, vale más olor de jarra que sabor de cisterna".

71. Josep Hernando. "Els moralistes i l'alimentatió a la baixa Edat Mitjana" in Alimentació i societat a la Catalunya medieval. Barcelona: Consell Superior d'Investigacions Científiques. Institució Milà i Fontanals. Unitat d'Investigació d'Estudis Medievals. 1988, pp. 271-293 (p. 283). Para la trad. del texto sigo la de J. L. Martín Rodríguez (Op. cit., p. 25): "Una vez distendido el vientre por los alimentos e irrigado con las bebidas de vino, se sigue la voluptuosidad de la lujuria, la ebriedad es el fomento de la sensualidad, la ebriedad rompe el sello de la castidad, por ello se siguen las fornicaciones, huyamos de la ebriedad no sea que caigamos en las redes de la lujuria, nutre la llama de las fornicaciones, incita a la sensualidad, por naturaleza el vino y la adolescencia son un doble incendio de la voluptuosidad". 
por el propio Andreas Capellanus en su Tratado del amor cortés supuestamente escrito para defensa de este amor y loa de las damas gentiles que lo profesan ${ }^{72}$.

Otros efectos de la ebriedad es que propicia la pereza y el abandono del deber. Bernardo de Claraval así lo advierte en su Apología a los cluniacenses "cuando ya las venas se hinchan con tanto vino qué puede hacer sino echarse a dormir..."73. Además, este "apetito desordenado en el beber" (gula) hace que los hombres olviden su prudencia ${ }^{74}$, lo que genera numerosos males, entre ellos, las riñas y los crímenes ${ }^{75}$ que rebasan lo individual para afectar de lleno a lo social.

En cuanto a los efectos físicos, hay quien piensa que "el mal vino" afecta al organismo dejando pruebas evidentes. Henri d'Andeli en su obra La Bataille des $v_{\text {vins }}{ }^{76}$ menciona cómo los malos vinos hinchan el vientre ("Sire Pétard de Châlons"), producen retortijones en el estómago ("Et encore maître Rouget d'Étampes, qui provoque des crampes d'estomac"), o dejan ciego ("le Vaillant vin blanc de Poitiers [...] il est si âcre [...] Je ne sais plus qui en but bien trop et en devint aveugle"). De este mismo mal se ve aquejado el propio poeta al beber el fuerte vino de Saint Jean d'Andeli que le "a crevé les yeux". Lo cierto es que son muchos los textos y autores que tratan de los problemas y enfermedades que produce el vino $y$, sobre todo, la embriaguez tanto en el cuerpo como en la mente. Para ejemplificarlo seguimos los datos aportados por Josep Hernando. En lo corporal son claros sus estragos que pueden, en el peor de los casos, producir la muerte:

Corpus debilitat, corrumpit sanguinem, obtundit visum, pertubat venas, infirmat nervos, obturat aures, turbat viscera, subvertit sensum, humectat cerebrum, debilitat membra [...] Paralysis, hydropisis, morbus caducus, stomachi tormenta, capitis vertigo, viscerorum distensio [...] Ex hoc enim multorum membra cibos recusant, et vino dedita, praecoqua debilitate et cruda senectute macescunt, et adhuc aetate viride tremula vibratione

72. Vid. Andreas Capellanus. De amore: Tratado sobre el amor. Texto original, trad. y notas de Inés Creixell Vidal-Quadras. Barcelona: Sirmio, 1990.

73. Apología, Op. cit., p. 281.

74. Bernardo de Claraval en su Lettre XLII hace costar este efecto negativo sirviéndose en esta ocasión del Salmo CVI, 23,26, 27: "troublés comme des hommes plongés dans le vin, la tête leur tourne et leur sagesse les abandonne". Bernard de Clairvaux. Lettres, t. II (42-91). Ed. de Monique DuchetSuchaux. París: Les Éditions du Cerf, 2001.

75. En el Libro del Buen Amor, don Amor cuenta la historia del ermitaño que se perdió porque bebió vino "mucho vino sin tiento"; la embriaguez dio paso a la lujuria y ésta lo arrastró al homicidio. Juan Ruiz Arciprestre de Hita. Libro del Buen Amor. Ed. cit., 528-543.

76. La Bataille des vins (s. XIII) es una alegoría jocosa en la que distintos vinos de Francia y de otros países son entidades (personificación) que disputan entre ellos para conseguir el primer puesto, es decir, el reconocimiento de excelencia. Remitimos a la trad. al francés moderno de A. Corbellari. Les dits d'Henri d'Andeli. París: Honoré Champion, col. "Traductions des classiques du Moyen-Âge, 2003. 
quassantur; inde pulmones ustione vini quotidie putrescunt et per ora veluti mortuorum spiritus tetros mittunt; in his ergo talibus non ratio ulla, non ullum gerendae vitae consilium, non gestorum aut lectionum memoria, nec ulla artium aut industriae providentia ${ }^{77}$.

Los efectos mentales o psíquicos ("mentis alienatio") tampoco se olvidan: "Primum abolet memoriam, dissipat sensum, negligit mentem, confundit intellectum, involvit linguam, implicat verba, obliquat lumina"78. Además de enajenar la mente, la embriaguez cambia el carácter, aumenta la ira, la irritación, la soberbia, en una palabra estimula la maldad, y si es muy aguda, puede propiciar el delirium tremens ${ }^{79}$. El autor del Libro del Buen Amor habla muy claro sobre la perdición que acarrea la falta de mesura en el beber:

Es el vino muy bueno en su mesma natura,

Muchas bondades tiene si s' toma con mesura;

Al que de más lo beve sácalo de cordura:

Toda maldat del mundo faze e toda locura; (548)

Sin embargo, y como ya avanzábamos, las imágenes de ruina material y espiritual no siempre se acompañan de un halo de tristeza y sufrimiento. A pesar del rechazo social y de las recriminaciones de moralistas, tratadistas, galenos... los buenos bebedores, esos que beben mucho y bien, se muestran siempre contentos de catar un buen vino, y su vida gira en torno al beber y su mundo porque, como dicen muchas canciones de los Carmina Burana:

\author{
Cuando estamos en la taberna \\ nada nos preocupa la muerte; \\ en el juego nos concentramos \\ y al juego, sin cesar, nos dedicamos... \\ Allí nadie teme la muerte, \\ todos a Baco confían su suerte ${ }^{80}$.
}

77. Op. cit., p. 283. Traducción: "Debilita el cuerpo, corrompe la sangre, debilita la visión, perturba las venas, debilita los nervios, obtura los oídos, turba los intestinos, trastorna el sentido, ablanda el cerebro, debilita los miembros, produce parálisis, hidropesía, epilepsia, tormentos del estómago, vértigo, distensión de los intestinos... Los miembros de muchos dados al vino rechazan los alimentos, enflaquecen por una precoz debilidad y por una cruel vejez e incluso, estando en edad vigorosa, se agitan con un trémula vibración. De ahí que sus pulmones por el ardor del vino poco a poco se pudren y por sus bocas echan repugnantes alientos, cual si fuesen de muertos, En estos tales no hay razón alguna, no cabe consejo alguno de cambio de vida, no retienen nada de lo que cabe hacer o decir, ni aprenden arte ni actividad alguna".

78. Ibid. Trad. "Primero anula la memoria, trastorna el sentido, desprecia la mente, confunde el intelecto, traba la lengua, embrolla las palabras".

79. Un ejemplo de este aparece en los Milagros de Nuestra Señora de Gonzalo de Berceo. Es el caso del monje que se emborracha hasta perder la consciencia y cuando vuelve en sí bajo los efectos de la resaca cree ver sucesivas apariciones del demonio con forma de toro bravo, de perro rabioso y de león (Vid. ed. cit.).

80. Trad. de la edición latina de Jean Petit. Carmina Burana. Barcelona: Sinera, 1968, p. 34. 
El vino contribuye en mucho a crear una visión epicúrea de la existencia al suavizar, e incluso, invertir sus aspectos más negativos. Se vive con una idea dominante: el carpe diem, es decir, "bebe y goza de la vida pues la vida se va":

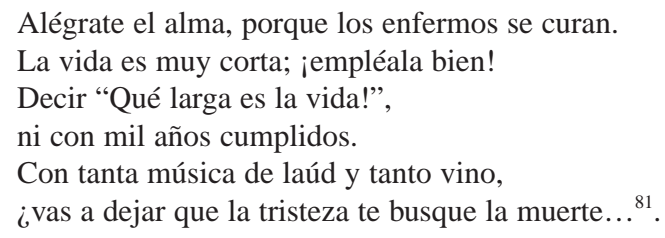

Y cuando por fin llega la muerte, el difunto se asegura de que no le falte vino, su buen compañero. Tras una vida alegre se sueña una muerte igualmente alegre. Así la sueña el poeta Ibn Gabirol:

Si yo muero antes que tú, amado mío, cava mi tumba entre las raíces de los viñedos.

Lava mi cuerpo con el zumo de las uvas y embalsámame con agraces y perfumes.

No llores ni te lamentes por mi muerte, y no pongas sobre mi tumba polvo, sino odres nuevos con vinos añejos ${ }^{82}$.

\section{O Ibn Quzmân:}

Cuando muera, mi modo de enterramiento sea yacer bajo las cepas en viña: pámpanos juntadme, de mortaja, encima, y a la cabeza un turbante de sarmientos.

El demonio convoque allí a todo amigo, invocádmelo, tanto sentados como de pie, y quien coma racimo de uvas, entierre en mi tumba el escobajo ${ }^{83}$.

Y, desde luego, todos recordamos muy bien una cancioncilla popular que se expresa en términos similares: "Cuando yo me muera / tengo ya dispuesto / en el testamento / que me han de enterrar / en una bodega / al pie de una cuba / con un grano de uva / en el paladar / en el paladar...”. Esta asociación de imágenes (muerte-tumba-

81. Poema del poeta andalusí Al-Mu 'tamid in Antología de la Poesía Andalusí. Edición de Manuel Francisco Reina. Trad. de Teresa Garulo, Miguel José Hagerty y Muhsin al-Ramli. Madrid: Edaf, 2007, 309.

82. Selomoh Ibn Gabirol. Cantos de amor y muerte. Ed. y estudio de $\mathrm{M}^{\mathrm{a}}$ José Cano. Granada: Universidad de Granada, 2007, 1058.

83. Ibn Quzmân. Cancionero andalusí. Ed. de Federico Corriente. Madrid: Hiperíon, 1989, 90. 
viña-vino) aparece también en el arte funerario cristiano en el que se multiplican los motivos de las viñas, de la vendimia y del vino, lo que prueba, una vez más, que éste es considerado como una bebida de vida, en el sentido de inmortalidad.

La aparición reiterada de estas imágenes en autores de países, culturas y religiones diferentes indica que éstas se enraízan en el consciente colectivo. La muerte se eufemiza al desprenderse del halo trágico que acompaña la finitud temporal. La clave parece encontrarse en el hecho de relacionar el vino, la tierra ("le terroir") y la viña con el difunto, ya que esta asociación con el simbolismo vegetal-agrario (la vegetación se mantiene en un continuum temporal marcado por las estaciones $^{84}$ ) permite al difunto beneficiarse del carácter "imperecedero" de dicho simbolismo. Dicho de otro modo, el vino inmortal alimenta al difunto, deviniendo él mismo inmortal. Efectivamente, en estos poemas báquicos vemos cómo confluyen dos trayectos simbólicos complementarios: el del reposo (la tumba), y el alimentario: la planta nutricia (vid-viña y su jugo el vino). En el primer caso, la tumba deviene la morada última tras la muerte, todo ello sugerido por la idea de involución que representa el "retorno a la madre" (regressus at uterum). La tumba es un símbolo del Arquetipo de la Madre que refuerza la protección y seguridad del muerto ${ }^{85}$ ya que éste descansa doblemente envuelto en la madre (tierraataúd), duplicándose con ello las garantías de reposo. En el segundo caso, "el descanso en la madre" está ligado al "Gran Arquetipo del alimento Primordial" modo que la mención a la planta nutricia y al vino recrea de nuevo la imagen materna pero esta vez en su función nutricia puesto que alimenta al muerto ${ }^{87}$. En el caso que nos ocupa la leche (alimento primordial) es sustituida por vino considerado por los grandes bebedores como su alimento vital. El vino aparece en la preparación del cuerpo del difunto ("lava mi cuerpo con el zumo de las uvas" o "lava mi cuerpo con el vino más rojo") y en los odres con "vinos añejos" que lo acompañan en la tumba. Indirectamente, el vino está también representado en los viñedos donde el muerto quiere ser enterrado.

En definitiva, la muerte es apreciada como estado de bienestar ya que el difunto tiene todo lo que necesita: intimidad, descanso, abrigo y alimento. Esto explica la revalorización de la muerte, vista como otra forma de vida en la no-

84. Durand. Op. cit., pp. 339-340. Véase también Mircea Eliade. El mito del eterno retorno. Arquetipos y repetición. Madrid: Alianza/Emecé, 1982.

85. Vid. C. G. Jung. Símbolos de Transformación. Buenos Aires: Paidós, 1982.

86. Vid. Durand. Op. cit., p. 223.

87. "Muy frecuentemente esta acentuación del carácter lactífero y nutricio de la Diosa hace anastomosarse el arquetipo de la Madre con el del árbol o el de la planta lactífera” (Durand. Op. cit., p. 246.). 
vida, y la eufemización de la tumba en morada dichosa para un reposo feliz. Estamos, por lo tanto, ante una visión alegre de la muerte al trivializarla como un tránsito a otra forma de vida más plena y dichosa, la inmortalidad ${ }^{88}$.

Por último, el vino báquico no es sólo el de la borrachera, sino también el que despierta la inspiración. Aquí ya no se trata de la ebriedad sino de la embriaguez o lucidez creativa del poeta. Lamentablemente, la retórica medieval no contempla este concepto aunque hay ejemplos poéticos que vinculan el vino y la embriaguez con la inspiración poética ${ }^{89}$. Uno de ellos es el que aparece en el texto anónimo del siglo XIII, La desputoison du vin et de l'iaue (La dispute du vin et de l'eau):

Je fui l'autr'ier a une feste.
Au partir me dolut la teste,
Pour ce que je bus vins divers;
En mon chief monterent li vers
Qui me firent ce dit diter,
Que vous m'orrez ci recorder (v. 1-6)

\section{Conclusión}

En la Edad Media se bebe vino porque forma parte de la vida cotidiana, y porque el vino, como la comida, se asocia en el consciente colectivo con la idea de felicidad y prosperidad. A veces se bebe mucho incurriendo en la ebriedad. Las razones pueden ser múltiples: disfrutar de un momento de libertad o felicidad en este valle de lágrimas olvidando el miedo al infierno que tanto atenaza las conciencias; olvidarse de sí mismos, de su situación ... Sea por lo que fuere el caso es que se bebe vino, y mucho.

El vino, como hemos mostrado, presenta dos caras dentro del imaginario de la cultura medieval y, por lo tanto, dentro de la literatura. Una cara de "gloria" y "exaltación", cantada por doquier ya que se une a la vida en su lado más positivo

88. "En cierto sentido el muerto es encerrado en la madre a fin de renacer" (Jung, Op. cit., 247). Véase también Mircea Eliade. Tratado de Historia de las religiones. Morfología y dinámica de lo sagrado. Madrid: Eds. Cristiandad, 1981, cap. VIII: "La vegetación, símbolos y ritos de renovación".

89. Sobre la resonancia de este concepto en la poesía de trovadores remitimos al artículo de Alain Corbellari, "Le cheval, le sommeil et le vin. Considérations sur l'inspiration poétique au Moyen Âge", Revue des langues romanes $\mathrm{n}^{\circ} 1,2006$, pp. 205-216.

90. La Desputoison du vin et de l'iaue (XIIIe siècle). Texto reproducido por A. Henry en su obra Contribution à l'étude du langage anologique en langue d'oül (XII-XVe s.), t. I. Bélgica: Académie Royale de Belgique. 1996, p. 138. 
y resplandeciente: contribuye al jolgorio general y el regocijo particular, anima a los corazones, mueve a la hospitalidad, a la generosidad y mejora la convivencia social (reuniones, fiestas y festejos, convites...). Pero el vino, como hemos visto, tiene otra cara más lúgubre de "ignominia" para los que lo juzgan con severidad. El vino es, entonces, envilecido por su naturaleza nociva y denostado por sus efectos: expande la tristeza (melancolía), conduce a la quiebra material y a la embriaguez (pecado que simboliza la muerte del alma), ambas excluyen al individuo del marco de las relaciones sociales; produce la enfermedad y la muerte. Esta decadencia moral y material asocian el vino con el lado opuesto a la vida: la muerte. Una dualidad que se alterna, como las dos caras de una moneda, a lo largo de la vida y que no puede separarse la una de la otra.

Así pues, uno de los vectores que rige el imaginario medieval del vino es el hecho de considerarlo un "farmakon" (Platón) en el sentido de ser al mismo tiempo "remedio curativo" y "bebida nociva" para el cuerpo y el alma. La ambivalencia unas veces y la ambigüedad otras marcan el vino y lo enológico en la Edad Media, una era profundamente sancionada por los valores religiosos. Y a pesar de esto, la necesidad del hombre medieval de ser feliz desligándose de las reglas impuestas sale a flote en momentos de libertad suprema recogidos en los textos, voces que afianzan al individuo y exaltan el vino, el beber y la taberna. El aliento único de los seguidores de Baco de no dejarse dominar en esa búsqueda perpetúa de la felicidad conduce al prodigio de exorcizar los terrores que impone la muerte, de modo que en su seno mismo se opera el cambio y el rostro tenebroso cede a la esperanza de la inmortalidad.

\section{Bibliografía}

ANDRÉ, J.- M. "Vertu thérapeutique du vin et pathologie de l'ivresse à Rome, de Lucrèce à Pline l'ancien" in Actes du XXe Congrès Les Ecrivains et le Sacré. La vigne et le vin dans la littérature. 2eme partie. París: Les Belles Lettres, 1989, pp. 450-2.

Antología de la Poesía Andalusí. Edición de Manuel Francisco Reina. Trad. de Teresa Garulo, Miguel José Hagerty y Muhsin al-Ramli. Madrid: Edaf, 2007. ARIAS, R. La poesía de los goliardos. Madrid: Gredos, 1970.

ASENJO, M. "Integración y exclusión. Vicios y pecados en la convivencia urbana", in Pecar en la Edad Media. Coords. Ana Isabel Carrasco y Mª Pilar. Rábade. Madrid: Silex, 2008, pp. 185-207.

BACHELARD, G. La Terre et les rêveries du repos. París: José Corti, 1948. 
BERCEO, Gonzalo de. Obra Completa. Ed. crítica de B. Dutton. Madrid: Espasa-Calpe, 1992.

BERNARDO DE CLARAVAL. Obras Completas. Edición de los Monjes Cistercienses de España. Madrid: Biblioteca de Autores Cristianos (BAC), 1993.

BERNARD DE CLAIRVAUX. Lettres, t. II. Ed. de Monique Duchet-Suchaux. París: Les Éditions du Cerf, 2001.

BIDEAUX, M., O'HANION, R. et PICARD, J.-M. (eds,). Rabelais-Dionysos, vin, carnaval, ivresse. Montpellier: Jeanne Laffitte, 1997.

CAPELLANUS, A. De amore: Tratado sobre el amor. Texto original, trad. y notas de Inés Creixell Vidal-Quadras. Barcelona: Sirmio, 1990.

CARDINI, F. "Hoc est sanguis meus. Le vin dans l'Occident médiéval" in Le Ferment Divin. Paris: Éditions de la Maison des Sciences de l'homme, 1991, pp. 101-107.

Carmina Burana. Ed. de Joan Petit. Barcelona: Sinera, 1998.

CHRÉTIEN DE TROYES. Erec et Enide. Ed. de M. Roques. Paris: Honoré Champion, col. "C.F.M.A.", 1978.

CHRÉTIEN DE TROYES. Le Chevalier au lion (Yvain). Ed. de Mario Roques. París: Honoré Champion, col. "CFMA", 1982.

CHRÉTIEN DE TROYES. Le conte du Graal (Perceval). Ed. de Félix Lecoy. Paris: Honoré Champion, col. “C.F.M.A.”. T I (1979), T. II (1984).

CORBELLARI, A. La voix des clercs. Littérature et savoir universitaire autour des dits du XIIIe siècle. Ginebra: Droz, 2005.

CORBELLARI, A. "Le cheval, le sommeil et le vin. Considérations sur l'inspiration poétique au Moyen Âge", Revue des langues romanes $\mathrm{n}^{\circ}$ 1, 2006, pp. 205-216.

D'ANDELI, H. La Bataille des vins. Ed. y trad. de A. Corbellari. Les dits d'Henri D'Andeli. París: Honoré Champion, 2003.

DELORT, R. La vie au Moye-Âge. París: Seuil, col. "Points", 1982.

Deuxième Continuation de Perceval (The continuations of the old Franch "Perceval” of Chrétien de Troyes). Ed. de W. Roach, t. IV. Filadelfia, 1971.

La Desputoison du vin et de l'iaue (XIIIe siècle). Texto reproducido por A. Henry. Contribution à l'étude du langage cenologique en langue d'oül (XII-XVe s.), t. I. Bélgica: Académie Royale de Belgique. 1996.

DON JUAN MANUEL. Obras Completas. Ed. de José Mª Blecua. Madrid: Gredos, 1981, t. I.

DURAND, G. Les estructures anthropologiques de l'imaginaire. París: Bordas, 1981.

ELIADE, M. El mito del eterno retorno. Arquetipos y repetición. Madrid: Alianza/Emecé, 1982. 
ELIADE, M. Tratado de Historia de las religiones. Morfología y dinámica de lo sagrado. Madrid: Eds. Cristiandad, 1981.

GOUREVITCH, A. Les catégories de la culture médiévale. París: Gallimard, 1972.

GUERMÈS, S. Le vin et l'encre. La littérature française et le vin du XIIIe siècle au Xxe siècle. Bordeaux: Eds. Mollat, 1995.

GERBERT DE MONTREUIL. La Continuation de Perceval, T I y II. Ed. de M. Williams. París: Honoré Champion, col. "CFMA", 1922-25. T. III ed. de M. Oswald, 1975.

GUERREAU-JALABERT, A. "Aliments symboliques et symbolique de la table dans les roman arthuriens (XIIe et XIIIe siècles)", in Annales ESC, mai-juin, 1992, no 3, pp. 561-594.

HERNANDO, J. "Els moralistes i l'alimentatió a la baixa Edat Mitjana" in Alimentació i societat a la Catalunya medieval. Barcelona: Consell Superior d'Investigacions Científiques. Institució Milà i Fontanals. Unitat d'Investigació d'Estudis Medievals. 1988, pp. 271-293.

HERRERA, $\mathrm{M}^{\mathrm{a}}$ T. Tratado de las apostemas de Diego El covo. Salamanca: Servicio de Publicaciones de la Universidad de Salamanca, 1983.

IBN GABIROL, S. Cantos de amor y muerte. Ed. y estudio de $\mathrm{M}^{\mathrm{a}}$ José Cano. Granada: Universidad de Granada, 2007.

IBN QUZMÂN. Cancionero andalusí. Ed. de Federico Corriente. Madrid: Hiperíon, 1989.

JUAN RUIZ ARCIPRESTE DE HITA. Libro del Buen Amor. Ed. de Alberto Blecua. Madrid: Cátedra, 1992.

JUNCOSA, E. "Vinum et ebrietas auferun cor. La condena moral por embriaguez según Francesc Eisimenis" in Pecar en la Edad Media. Coords. Ana Isabel Carrasco y Mª Pilar. Rábade. Madrid: Silex, 2008, pp. 263-278.

JUNG, C. G. Símbolos de Transformación. Buenos Aires: Paidós, 1982.

La Mort du roi Arthur. Ed. de M. Santucci. Paris: Honoré Champion, col. "C.F.M.A.", 2005.

LA SALLE, A. de. Jehan de Saintré. Ed. de J. Misrahi et Ch. A. Knudson. Ginebra: Droz, 1967.

L’Âtre périlleux. Ed. de Brian Woledge. París: Honoré Champion, col. "C.F.M.A.", 1936.

LE GOFF, J. La civilisation de l'Occident médiéval. París: Champs-Flammarions, 1982 (1964).

LE GOFF, J. Pour un autre Moyen Âge. Temps, travail et culture en Occident. París: Gallimard, col. "Bibliothèque des Histoires", 1977.

Le Guide du Pèlerin de Saint-Jacques de Compostelle. Ed. y trad. de Jeanne Vielliard. París: Librairie Philosophique J. Vrin, 1990. 
Le Secret des Secrets (Secretum Secretorum). Ms. Baltimore s. XV. Ed. y trad. de Denis Lorée. Walters Arts Gallery, W 308.

Los Fabliaux. Ed. de Josefa López Alcaraz. Murcia: Servicio de Publicaciones de la Universidad de Murcia, 2003.

MARTÍN RODRÍGUEZ, José Luis. El vino y la buena mesa medieval. Logroño: Universidad Nacional de Educación a Distancia (UNED), La Rioja, 1998.

NADALES, $M^{\mathrm{a}}$ R. "La mujer y el vino en la literatura: Historia de un desencuentro", Boletín de la Real Academia de Córdoba de Ciencias, Bellas Artes y Nobles Artes, ${ }^{\circ}$ 146, 2004, pp. 321-4.

PASTOUREAU, M. La vie quotidienne en France et en Angleterre au temps des chevalier de la Table Ronde. Paris: Hachette, 1976.

PAYEN, J.-C. Le motif du repentir dans la littérature française médiévale. Des origines à 1.230. Ginebra: Droz, 1968.

PÉRÈS, H. Esplendor de al-Andalus. Madrid: Hiperión, 1990.

RENAUT DE BEAUJEU. Le Bel Inconnu. Ed. de G. Perrie Williams. Paris: Honoré Champion, col. "C.F.M.A.”, 1983.

RIQUER, Martín de. Los trovadores. Barcelona: Ariel, 1992.

ROUGEMONT, D. L'Amour et l'Occident. París: Plon, 1956.

SALINERO, M. J. "La cultura del vino en la Edad Media. Presencia y función del vino en la narrativa caballeresca" in Angles Santa y Cristina Solé (eds.). Texto y Sociedad en las letras francesas y francófonas. Lérida: Universidad de Lérida, 2009, pp. 57-68. 